\title{
DETERMINAN FAKTOR YANG BERPENGARUH ATAS KUALITAS AUDIT PADA KANTOR AKUNTAN PUBLIK
}

\author{
Ade Trisyanto \\ Program Studi Akuntansi, Universitas Buana Perjuangan Karawang, Indonesia, \\ adetrisyanto@ubpkarawang.ac.id
}

\begin{abstract}
Quantitative financial information for internal and external parties is summarized in output which must be relevant and reliable. In carrying out their audit duties, auditors must adhere to the auditing standards set by the Indonesian Institute of Certified Public Accountants (IAPI), which aims to improve audit quality. This study aims to analyze and prove empirically the determinant factors that influence audit quality at the Public Accounting Firm (PAF), which consist of auditor ethics, competence, audit fees and time pressure budget. This type of research is explanatory with a quantitative analysis approach. The sampling technique used purposive sampling, which requires that the respondent is an external auditor who works at a Public Accounting Firm (KAP) in the Jakarta area with a final sample of 63 people. The results of the study are: (1) auditor ethics and audit fees have a significant positive effect on audit quality (2) Competence has a significant negative effect on audit quality (3) Time pressure budget has no significant effect on audit quality.
\end{abstract}

Keywords: auditor ethics, audit fees, audit quality.

\begin{abstract}
Abstrak
Informasi keuangan yang sifatnya kuantitatif bagi pihak internal maupun eksternal dirangkum dalam output yang harus relevan serta dapat diandalkan. Auditor dalam melaksanakan tugas pemeriksaannya harus berpedoman pada standar audit yang telah ditetapkan oleh Institut Akuntan Publik Indonesia (IAPI), hal ini bertujuan untuk meningkatkan kualitas audit. Penelitian ini bertujuan untuk menganalisis dan membuktikan secara empiris determinan faktor yang berpengaruh atas kualitas audit pada Kantor Akuntan Publik (KAP) yang terdiri dari etika auditor, kompetensi, fee audit serta time pressure budget. Jenis penelitian ini merupakan eksplanatori dengan pendekatan analisis kuantitatif. Teknik sampling menggunakan purposive sampling yang mensyaratkan bahwa responden adalah auditor eksternal yang bekerja pada Kantor Akuntan Publik (KAP) di wilayah Jakarta dengan sampel akhir sebanyak 63 orang. Hasil penelitian yaitu: (1) Etika auditor dan fee audit berpengaruh positif secara signifikan atas kualitas audit (2) Kompetensi berpengaruh negatif secara signifikan atas kualitas audit (3) Time pressure budget tidak berpengaruh signifikan terhadap kualitas audit.
\end{abstract}

Kata Kunci: etika auditor, fee audit, kualitas audit.

\section{PENDAHULUAN}

Informasi keuangan yang sifatnya kuantitatif bagi pihak internal maupun eksternal dirangkum dalam output berupa laporan keuangan. Laporan keuangan memiliki 2 (dua) karakteristik penting yakni menurut FASB, dimana laporan keuangan harus relevan (relevance) serta dapat diandalkan (reliable) (Adnan, 2017, hal. 1). Singgih dan Bawono (2010), kedua karakteristik tersebut sangatlah sulit untuk diukur. Kondisi ini menuntut stakeholders untuk dijamin bahwa laporan keuangan tersebut dapat diandalkan serta relevan yang oleh karenanya jasa pihak ketiga yaitu auditor independen sangatlah dibutuhkan (Tjun, Marpaung, \& Setiawan, 2012). Profesi akuntan publik merupakan profesi kepercayaan masyarakat serta memiliki peranan penting dalam penyediaan informasi keuangan yang handal bagi pemerintah, investor, kreditor, pemegang saham, karyawan, debitur, juga bagi masyarakat dan pihakpihak lain yang berkepentingan (Nurhayati, 2017). Menurut Rapina, dkk. (2010), tanggungjawab profesi akuntan publik bagaimana meningkatkan keandalan laporan keuangan perusahaan, sehingga masyarakat memperoleh informasi laporan keuangan yang andal sebagai dasar pengambilan keputusan. Masyarakat mengharapkan penilaian yang bebas dan tidak memihak terhadap informasi yang disajikan oleh manajemen perusahaan dalam laporan keuangan.

Auditor dalam melaksanakan tugas pemeriksaannya harus berpedoman pada standar audit yang telah ditetapkan oleh Institut Akuntan Publik Indonesia (IAPI) dalam hal ini SPAP (2013), yaitu standar 
umum, standar pekerjaan lapangan dan standar pelaporan untuk penunjang profesionalisme sebagai akuntan publik. Standar umum merupakan standar yang mengharuskan auditor memiliki keahlian dan pelatihan teknis yang cukup dalam melaksanakan prosedur audit. Standar pekerjaan lapangan dan standar pelaporan berupa standar yang mengatur auditor untuk mengumpulkan data dan kegiatan lainnya selama proses audit serta mewajibkan auditor untuk menyusun suatu laporan atas laporan keuangan yang diauditnya secara keseluruhan (Aditia, 2016, hal. 3). Kedua hal ini harus ditunjang dengan adanya perangkat lunak audit yang memadai yang mayoritas digunakan di Indonesia, seperti Active Data for Excel, Audit Command Language (ACL), ERP Audit, dan Top CAAT's, kondisi ini dapat secara efisien dan mengefektifkan dalam penugasan audit yang terkadang masih kurang dimaksimalkan oleh kantor akuntan publik (KAP) (Husain, 2017). Menurut Lianto dan Kusuma (2010), audit laporan keuangan apakah laporan keuangan auditee menyajikan secara wajar atau tidak atas prinsip akuntansi sangat ditentukan oleh waktu atau lamanya penyelesaian audit (Trisyanto, 2019). Di samping itu, dimensi profitabilitas tidak terlepas dari pengukuran atas kinerja keuangan (Khristiana \& Sapariyah, 2016).

Menurut Kell et al. (2002), etika menggambarkan pernyataan atas bagaimana orang akan berperilaku terhadap sesamanya. Etika terkait dengan kompetensi yang merupakan konstruk dari komponen kualitas audit yaitu adanya standar etika yang tinggi (Alim, Hapsari, \& Purwanti, 2007). Menurut IAPI (2013), auditor dituntut memegang teguh etika profesi. Etika auditor tentunya menjadi isu yang sangat menarik, dimana situasi persaingan tidak sehat dapat dihindarkan. Etika juga membutuhkan pertimbangan yang mewakili kebutuhan auditor untuk menjustifikasi atau mengungkapkan suatu kebenaran atas keputusan yang telah diambil. Pemahaman etika auditor sanga penting untuk mengukur tingkat setiap keputusan yang diambil dengan pertimbangan etika (Hanjani \& Rahardja, 2014). Auditor juga harus memenuhi kriteria kompetensi yang dimiliki individu. Aspek kompetensi ini melekat pada individu yang mencakup nilai, sikap, keterampilan, pengetahuan, dan sifat yang mengarahkan ke tingkah laku untuk mencapai kinerja audit (Alim, Hapsari, \& Purwanti, 2007). Pengalaman juga melekat pada faktor keterampilan dan pengetahuan yang diperoleh seseorang setelah menyelesaikan sesuatu yang juga pelatihan-pelatihan yang diikuti oleh auditor (Singgih \& Bawono, 2010). Aspek di atas lebih berfokus pada subjektifitas auditor yang bersangkutan untuk melakukan analisis kertas kerja, pengungkapan fakta-fakta, pertimbangan khusus serta pengalaman dari pihak internal dan eksternal (Ridwan \& Husain, 2017).

Faktor lainnya yang juga sangat penting yaitu fee audit. Menuru Dennis Y. Chung dan W. Daryl Lindsay (1988), kualitas audit ditentukan berdasarkan honorarium atau biaya audit berdasarkan dua faktor utama, yaitu total aset perusahaan untuk perusahaan skala besar dan jumlah piutang untuk perusahaan skala kecil (Purba, 2019). Penetapan fee audit yang dibayarkan perusahaan terlalu besar karena berdampak atas keuntungan pribadi, dan masih banyak yang lainnya yang dipersepsikan oleh banyak orang (Chrisdinawidanty, Tugiman, \& Muslih, 2016), sesuai dengan ketentuan Institut Akuntan Publik Indonesia. Struktur biaya dan pertimbangan profesional KAP dan lainnya terkait dengan banyaknya anak perusahaan dan karyawan yang dimiliki oleh auditee dalam kompleksitas perusahaan (Hanjani \& Rahardja, 2014). Menurut De Zoort (1998), time budget pressure dipahami atas terbatasnya ketersediaan sumberdaya dalam menyelesaikan pekerjaan atas munculnya tekanan, atau dengan kata lain sebagai waktu yang diberikan untuk menyelesaikan tugas (Cahaya Ningsih \& Yaniartha S., 2013). Auditor dalam konteks mencapai efisiensi atas anggaran waktu atau terdapat pembatasan waktu dan anggaran yang sangat ketat dituntut untuk melaksanakannya dengan baik (Sososutikno, 2003).

Beragamnya temuan penelitian yang menguji faktor kualitas audit diantaranya: (1) Konferensi pada Simposioum Nasional Akuntansi (SNA) ke-6 di Surabaya pada tahun 2003 yang menguji beberapa faktor antara lain time budget atas perilaku disfungsional dan dampaknya pada kualitas audit pada 130 sampel BEPEKA dan BPKP dengan hasil yang menyatakan bahwa time pressure budget tidak berpengaruh langsung pada kualitas audit, tetapi secara tidak langsung melalui perilaku disfungsionalitas dengan komponen under-reporting of time, premature sign-off dan audit quality reduction behavior 
(Sososutikno, 2003). (2) Konferensi pada Simposioum Nasional Akuntansi (SNA) ke-7 di Makassar pada tahun 2007 yang menguji kompetensi dan independensi terhadap kualitas audit pada masing-masing 5 (lima) auditor setiap KAP di Jawa Timur dengan hasil yang menyatakan bahwa kompetensi dan independesi berpengaruh signifikan terhadap kualitas audit sementara kompetensi yang diinteraksikan dengan etika auditor tidak berdampak pada kualitas audit (Alim, Hapsari, \& Purwanti, 2007). (3) Konferensi pada Simposioum Nasional Akuntansi (SNA) ke-8 di Purwekerto pada tahun 2010 pada 95 sampel auditor yang bekerja di KAP Big-Four dengan hasil yang menyatakan bahwa independensi, due professional care dan akuntabilitas auditor berdampak pada mempengaruhi kualitas audit sementara pengalaman tidak mempengaruhinya (Singgih \& Bawono, 2010). (4) Penelitian mengenai pelaksanaan kualitas audit pada auditor di kantor akuntan publik di Bandung sebanyak 53 orang dengan hasil yang membuktikan bahwa adanya pengaruh yang lemah atas independensi dengan kualitas pelaksanaan audit (Rapina, Saragi, \& Carolina, 2010). (5) Penelitian atas pengaruh kompetensi melalui dimensi pengetahuan dan pengalaman serta independensi auditor melalui dimensi lama hubungan dengan klien, tekanan klien, telaah dari rekan auditor, jasa non-audit atas kualitas audit. Hasil penelitian menyatakan bahwa kompetensi berpengaruh secara parsial terhadap kualitas audit dan independensi tidak berpengaruh terhadap kualitas audit (Tjun, Marpaung, \& Setiawan, 2012). (6) Penelitian mengenai independensi, kompetensi, time budget pressure pada 56 auditor yang dijadikan sampel atas KAP di Bali dengan hasil yang menyatakan bahwa independensi dan kompetensi berefek positif terhadap kualitas audit, sementara time budget pressure berefek negatif (Cahaya Ningsih \& Yaniartha S., 2013). (7) Penelitian mengenai kualitas audit dengan faktor etika, pengalaman, honorarium dan motivasi auditor pada masing-masing 10 (Sepuluh) auditor atas 13 (tiga belas) KAP di Semarang dengan hasil yang membuktikan bahwa keseluruhan faktor di atas berpengaruh positif dan signifikan atas kualitas audit (Hanjani \& Rahardja, 2014). (8) Penelitian atas kualitas audit yang dipengaruhi oleh independensi, kompentensi, etika auditor dan tekanan waktu pada sampel 171 auditor KAP yang bekerja di Jakarta dengan hasil yang menyatakan bahwa independensi, kompentensi, etika auditor memiliki pengaruh yang signifikan terhadap kualitas audit dengan arah positif, sementara tekanan waktu dengan arah negatif (Kurnia, Khomsiyah, \& Sofie, 2014). (9) Penelitian atas etika auditor dan fee audit dalam menentukan kualitas audit pada 54 auditor sampel atas KAP di Bandung dengan hasil yang menyatakan bahwa etika auditor dan fee audit berpengaruh positif dan signifikan terhadap kualitas audit (Chrisdinawidanty, Tugiman, \& Muslih, 2016).

Berdasarkan latarbelakang, dan gap penelitian yang didapat yaitu faktor etika dan kompetensi merupakan hal yang melekat pada individu auditor yang membuktikan pengaruh positifnya atas kualitas audit, sementara independensi beberapa penelitian menghasilkan pengaruh yang lemah (Rapina, Saragi, \& Carolina, 2010) serta tidak berdampak pada kualitas audit (Tjun, Marpaung, \& Setiawan, 2012). Faktor etika auditor juga berdampak positif atas kualitas audit namun etika auditor yang menjadi fungsi interaksi atas kompetensi tidak berdampak pada kualitas audit (Alim, Hapsari, \& Purwanti, 2007). Faktor fee audit juga berdampak positif atas kualitas audit (Hanjani \& Rahardja, 2014). Time budget and pressure dari klien juga tidak dapat dipisahkan faktor independensi atas dimensi tekanan audit tidak mampu membuktikan pengaruhnya atas kualitas audit (Sososutikno, 2003; Tjun, Marpaung, \& Setiawan, 2012), sementara berpengaruh negatif atas kualitas audit (Cahaya Ningsih \& Yaniartha S., 2013; Kurnia, Khomsiyah, \& Sofie, 2014), sementara faktor lainnya yang diuji bahwa kualitas audit tidak memiliki keterkaitan melalui rasio keuangan dan nilai perusahaan. Gap di atas melatarbelakangi penelitian ini untuk menganalisis dan membuktikan secara empiris determinan faktor yang berpengaruh atas kualitas audit pada Kantor Akuntan Publik (KAP) yang terdiri dari etika auditor, kompetensi, fee audit serta time pressure budget. Perbedaan penelitian ini adalah menggunakan subjek penelitian ini menggunakan persepsi auditor yang bekerja di KAP di Jakarta serta memfungsikan etika auditor dan time pressure budget sebagai faktor tersendiri (variabel inedependen) yang pada penelitian sebelumnya masih difungsikan sebagai dimensi dan variabel pemoderasi. 


\section{TINJAUAN PUSTAKA}

Teori keagenan (Agency Theory) yang diperkenalkan oleh M.C. Jensen dan W.H. Meckling pada tahun 1976 meupakan basis teori yang mendasari praktik bisnis perusahaan yang dipakai selama ini. Teori tersebut bermula dari penggabungan antara teori ekonomi, teori keputusan, sosiologi dan teori organisasi. Teori keagenan menjelaskan hubungan antara pemilik (prinsipal) dengan adanya perbedaan kepentingan stakeholders' yang berdampak pada konflik keagenan. Konflik ini terjadi karena kecenderungan agen perusahaan tidak bertindak sesuai dengan kepentingan prinsipal (Nurul Ichsany \& Husain, 2018). Dalam teori ini, munculnya asimetri informasi, yaitu adanya ketidaklengkapan informasi diantara kedua belah pihak sehingga stakeholders khususnya principal dan eksternal pemangku kepentingan membutuhkan kualitas audit dari pihak independen untuk meminimalisasi adanya asimetris informasi dan konflik keagenan.

Teori pensinyalan pada bukunya Accounting Theory: "whereby manager use the accounts to signal expectations and intentions regrading the future", artinya jika manajer mengharapkan perusahaan dengan tingkat pertumbuhan yang tinggi di masa depan, mereka akan mencoba memberikan sinyal kepada investor melalui akun-akun (Godfrey, Hodgson, Tarca, Hamilton, \& Holmes, 2010, hal. 375). Manajer perusahaan lain yang berkinerja baik akan memiliki insentif dan manajer dari perusahaan dengan berita yang netral akan sama memiliki insentif untuk melaporkan berita positif. sehingga tidak dicurigai memiliki hasil yang buruk.

\section{Etika Auditor}

Ethics can be defined broadly as a set of moral principles or values (Arens, Elder, \& Beasley, 2014, hal. 76), etika dapat dipahami yang menjadi perangkat nilai-nilai atau prinsip moral, jika terdapat aturan secara tertulis atas etika ini dapat disebut dekngan kode etik. IAPI mengatur secara nyata kode etik profesi auditor independen di Indonesia yang dikenal dengan istilah "Kode Etik Profesi Akuntan Publik". Etika dalam IAPI dapat diturunkan pada prinsip integritas, objektivitas, kompetensi dan perilaku profesional. Oleh karenanya, agar prinsip etika profesi akuntan publik dapat terus terjaga, kepercayaan yang telah diberikan harus dijaga atas apa yang menjadi tingkah laku dan telah diperbuat auditor telah sesuai dengan ketentuan yang berhubungan dengan standar dalam pekerjaannya. Pengukuran etika auditor mempertimbangkan tanggungjawab profesi, kepentingan publik, integritas, objektivitas, kompetensi dan kehati-hatian profesional, perilaku profesional dan standar teknis (Agoes, 2012, hal. 60; Chrisdinawidanty, Tugiman, \& Muslih, 2016). Di samping itu, etika juga tidak terlepas dari pertimbangan rasional yang mewakili kebutuhan dari keputusan etis yang telah dibuat sebagai suatu pertimbangan dengan harapan dapat mengungkapkan kebenaran (Hanjani \& Rahardja, 2014).

\section{Kompetensi}

IAPI berdasarkan SA Seksi 210 dalam SPAP, dengan Standar Umum Pertama menyatakan bahwa seeorang auditor harus memiliki keahlian dan pelatihan teknis yang cukup yang dapat melibatkan seseorang atau lebih dalam pelaksanaan audit. Lebih lanjut, Standar Umum Ketiga (SA Seksi 230) menyatakan bahwa kemahiran profesional dibutuhkan secara seksama dan cermat dalam pelaksanaan audit dan penyusunan laporannya (Tjun, Marpaung, \& Setiawan, 2012). Menurut Alim, dkk. (2007), kompetensi adalah seorang yang tercover dalam aspek-aspek pribadi yang memungkinkan untuk dapat mencapai kinerja yang maksimal atas seorang auditor (Cahaya Ningsih \& Yaniartha S., 2013).

\section{Fee Audit}

Menurut SOX, fee audit adalah biaya yang dibayarkan kepada auditor selama periode audit yang disebabkan adanya perubahan besar dalam lingkungan bisnis, peraturan dan profesional yang dihadapi oleh auditor sangat menentukan jangka waktu audit (Hoitash, Markelevich, \& Barragato, 2007). Lebih 
lanjut, honorarium audit adalah imbalan yang diterima dari kliean atau diberikan kepada pihak lain untuk memperoleh perikatan audit dalam bentuk barang, uang maupun bentuk lainnya (Agoes, 2012, hal. 56). Menurut Dennis Y. Chung dan W. Daryl Lindsay (1988), jasa audit fee bersifat kompleks dan sangat menentukan kualitas auditor dan KAP. Auditor cenderung membutuhkan fee dalam mendukung kebutuhan pelaksanaan audit, hal ini dilema bagi auditor maupun KAP yang mana klien akan lebih mudah dan murah mengganti auditornya dibandingkan auditor untuk mendapatkan fee tambahan atau alternatif sumber fee lain (Tjun, Marpaung, \& Setiawan, 2012). Faktor risiko sebagian besar sangat menentukan dalam pembiayaan audit, biaya yang lebih tinggi disebabkan oleh upaya audit yang lebih banyak (konsisten dengan kualitas audit yang lebih tinggi) (DeFond \& Zhang, 2014).

\section{Time Pressure Budget}

Menurut Ahituv dan Igbaria (1998) menyatakan kinerja seseorang akan ikut dipengaruhi oleh tekanan anggaran waktu (Cahaya Ningsih \& Yaniartha S., 2013). Auditor memiliki level atas time pressure yang berdampak pada seringkalinya auditor tidak tepat dalam melaksanakan perencanaan audit, hal ini berdampak pada menurunnya kualitas audit (Kurnia, Khomsiyah, \& Sofie, 2014). Auditor yang memiliki jam terbang yang tinggi berdampak pada tidak adanya tekanan waktu karena secara teknis maupun praktis menuntut auditor untuk segera menyelesaikan penugasan audit yang diberikan dengan hati-hati dan cepat sehingga memiliki tekanan tertentu (Ridwan \& Husain, 2017).

Grand theory, tinjauan pustaka dan temuan penelitian terdahulu untuk pengembangan model penelitian dengan logika IPO (input-process-output) dan kombinasi model kausal untuk merumuskan hipotesis alternatif (Sani, Pusparini, R., Khristiana, Zailani, \& Husain, 2020). Input berupa data-data yang direkam yaitu data primer yang diambil dari persepsi auditor yang bekerja pada Kantor Akuntan Publik (KAP) di Jakarta tentang Etika Auditor (X1), Kompetensi (X2), Fee Audit (X3), dan Time Pressure Budget (X4), yang kemudian diproses melalui metode analisis data dengan pendekatan statistik yang bertujuan untuk menghasilkan output yaitu tingkat atau level Kualitas Audit. Logika IPO inilah dalam istilah penelitian akademis berupa paradigma atau kerangka berpikir (framework of thinking) yang diturunkan menjadi model penelitian.

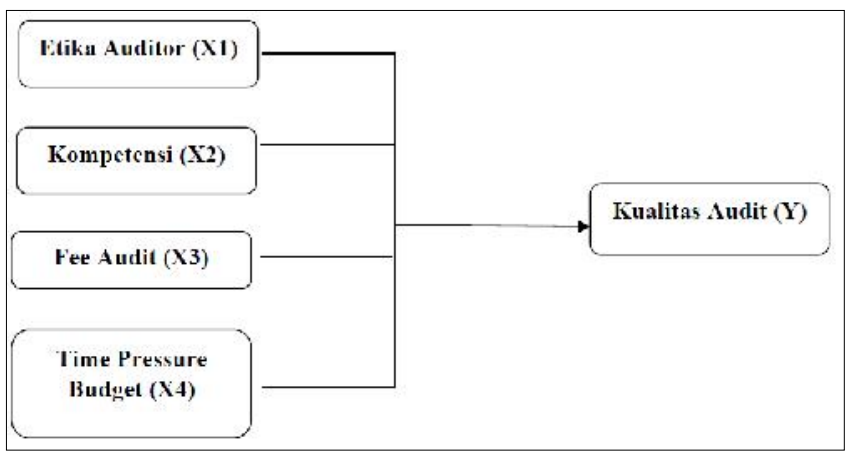

Gambar 1. Model Penelitian

Etika auditor dapat dipahami sebagai perangkat nilai, aturan secara tertulis (kode etik). IAPI mengatur kode etik profesi auditor independen dalam Standar Audit (SA). Etika auditor sangat menentukan keberhasilan suatu audit yang tertuang dalam kualitas. Hasil penelitian Alim, dkk. (2007) membuktikan dengan etika auditor tidak memoderasi pengaruh kompetensi dan independensi terhadap kualitas audit. Penelitian Hanjani dan Rahardja (2014), Kurnia, dkk. (2014), dan Chrisdinawidanty, dkk. (2016) menemukan pengaruh positif dan signifikan atas faktor etika terhadap kualitas audit. Kode etik tersebut berisi prinsip dasar dan aturan etika profesi yang harus diterapkan oleh setiap individu. Temuan penelitian di atas memiliki gap sehingga hipotesis pertama pada penelitian ini dirumuskan sebagai berikut:

$\mathrm{H}_{1}$ : Etika Auditor berpengaruh positif atas Kualitas Audit. 
Kompetensi adalah keahlian dan pelatihan teknis yang cukup yang dimiliki oleh seorang auditor atau lebih dalam pelaksanaan audit yang juga tertuang dalam Standar Audit (SA). Hasil penelitian Alim, dkk. (2007), Tjun, dkk. (2012), Cahaya Ningsih dan Yaniartha S. (2013) Kurnia, dkk. (2014) menemukan pengaruh positif dan signifikan atas faktor kompetensi terhadap kualitas audit. Pencapaian kompetensi dapat dicapai dan dimulai melalui pendidikan formal yang diperluas melalui pengalaman-pengalaman selanjutnya dalam praktik audit pendidikan formal dan pengalaman profesional saling melengkapi satu sama lain. Dengan demikian, hipotesis kedua pada penelitian ini akan kembali menguji:

$\mathrm{H}_{2}$ : Kompetensi berpengaruh positif atas Kualitas Audit.

Fee audit adalah kompensasi yang diberikan kepada auditor selama periode audit yang termuat dalam perikatan audit antara auditor atau KAP dengan klien atau auditee. Hasil penelitian Hanjani dan Rahardja (2014), Chrisdinawidanty, dkk. (2016) menemukan pengaruh positif dan signifikan atas faktor honorarium atau fee audit terhadap kualitas audit. Dengan demikian, hipotesis ketiga pada penelitian ini akan kembali menguji:

$\mathrm{H}_{3}$ : Fee Audit berpengaruh positif atas Kualitas Audit.

Auditor memiliki level atas time pressure merupakan suatu tolok ukur dan pedoman bagi suatu auditor untuk melaksanakan audit dalam ketepatan dalam perencanaannya yang sangat menentukan kualitas audit. Hasil penelitian Sososutikno (2003) tidak berpengaruh langsung atas kualitas audit, sementara penelitian Cahaya Ningsih dan Yaniartha S. (2013) serta Kurnia, dkk. (2014) membuktikan pengaruh negatifnya terhadap kualitas audit. Temuan penelitian di atas memiliki gap sehingga hipotesis keempat pada penelitian ini dirumuskan sebagai berikut:

$\mathrm{H}_{4}$ : Time Pressure Budget berpengaruh negatif atas Kualitas Audit.

\section{METODE}

Jenis penelitian ini merupakan eksplanatori (explanatory research) untuk menguji antar variabel yang dihipotesiskan untuk membuktikan kebenarannya. Hipotesis ini menggambarkan asosiasi antar variabel apakah variabel penyebab dipengaruhi atau tidak oleh variabel lainnya (Sani dan Maharani 2013). Penelitian ini menggunakan pendekatan kuantitatif, teknik sampling atas populasi yang merupakan auditor yang mempunyai pengalaman di atas 5 (lima) tahun atau menjabat sebagai manajer auditor di KAP yang berdomisili di Jakarta.

Pengumpulan data dilakukan dengan membagikan kuesioner langsung kepada responden ataupun melalui surat elektronik untuk diisi kemudian dikembalikan kepada peneliti yang berupa closed question yang meminta responden untuk memilih salah satu jawaban dengan memilih/klik (untuk kuesioner yang berupa link/website) pada opsi jawaban yang telah disediakan. Link ini menggunakan media https://drive.google.com yang dikirimkan melalui email dan media sosial seperti Whatsapp kepada teman kenalan yang berprofesi sebagai auditor. Semua intrumen ini diukur dengan menggunakan skala Likert (Kaptein, Nass, \& Markopoulos, 2010; Sani, Wiliani, \& Husain, 2019). Skala Likert menggunakan 5 (lima) gradasi dari tingkat sangat tidak setuju sampai dengan setuju (Sugiyono, 2018). Data penelitian tidak akan berguna jika instrumen yang digunakan untuk mengumpulkan data penelitian tidak memiliki validitas dan reliabilitas.

Tahap-tahap pengolahan data dalam penelitian ini dilakukan dengan analisis statistik deskriptif, uji kualitas data dan uji asumsi klasik untuk yang memberikan hasil best linear unbiasead estimator (BLUE). Model tersebut perlu diuji asumsi klasik dengan metode Ordinary Least Square (OLS) atau pengkat kuadrat terkecil biasa, jika model regresi dikatakan $B L U E$ apabila tidak terdapat Normalitas, Autokolerasi, Heteroskedastistas, dan Multikolinieritas. Uji hipotesis digunakan metode statistik regresi berganda (multiple regression) yang bertujuan untuk memprediksi besarnya kekuatan atau kontribusi atas pengaruh variabel independen terhadap variabel dependen. Penilaian terhadap ketepatan fungsi regresi 
berdasarkan Goodness of Fit yang diukur dengan nilai koefisien determinasi $\left(\mathrm{R}^{2}\right)$, nilai statistik $\mathrm{F}$, dan nilai statistik t diperlukan dalam analisis regresi ini.

\section{HASIL PENELITIAN}

Data primer yang diperoleh dan memenuhi syarat dalam pernyataan (kuesioner) yang telah didistribusikan kepada auditor di Kantor Akuntan Publik (KAP) di wilayah Jakarta dengan kriteria responden yang dipilih adalah yang telah bekerja minimal 5 (lima) tahun atau setidaknya yang telah menjabat sebagai manajer audit dengan hasil pada Tabel 1 berikut ini:

Tabel 1.Rincian Penyebaran dan Pengembalian Kuesioner

\begin{tabular}{|l|r|r|}
\hline \multicolumn{1}{|c|}{ Keterangan } & \multicolumn{2}{|c|}{ Responden (dalam) } \\
\cline { 2 - 3 } & Jumlah & Persentase (\%) \\
\hline Distribusi Kuesioner (Awal) & $\mathbf{2 0 0}$ & $\mathbf{1 0 0 , 0 0}$ \\
-/-: Kuesioner yang tidak kembali & $(75)$ & $(37,50)$ \\
Kuesioner yang kembali & 125 & 62,50 \\
-/-: Kuesioner yang tidak lengkap (diluar kriteria) & $\underline{(62)}$ & $(31,00)$ \\
Kuesioner yang Dapat Diolah & $\mathbf{6 3}$ & $\mathbf{3 1 , 5 0}$ \\
\hline
\end{tabular}

Sumber: Data Primer Diolah, 2020

Kuesioner akhir yang dapat diolah secara statistik sebanyak 63 responden dengan (respon rate) hanya 31,5 persen.

Tabel 2. Hasil Statistik Deskriptif

\begin{tabular}{|l|c|c|c|c|}
\hline & Minimum & Maximum & Mean & Std. Deviation \\
\hline Etika Auditor & 3,64 & 5,00 & 4,45 & 0,40 \\
\hline Kompetensi & 3,50 & 5,00 & 4,38 & 0,43 \\
\hline Fee Audit & 2,40 & 5,00 & 3,56 & 0,55 \\
\hline Time Pressure Budget & 2,50 & 5,00 & 3,68 & 0,65 \\
\hline Kualitas Audit & 1,00 & 5,00 & 4.04 & 1,07 \\
\hline Valid N (listwise) & \multicolumn{4}{|l}{} \\
\hline
\end{tabular}

Sumber: Data Diolah secara Statistik, 2020

Hasil statistik deskriptif yang disajikan pada Tabel 2, dapat dijelaskan bahwa variabel Etika Auditor memperoleh nilai minimum sebesar 3,64 dan maksimum sebesar 5,00. Dengan nilai rata-rata sebesar 4,45 dan standar deviasi sebesar 0,40. Hasil standar deviasi yang menunjukan kurang dari 1 menyatakan bahwa variabel Etika Auditor bersifat homogen. Pada variabel Kompetensi diketahui nilai minimum sebesar 3,50 dan maksimum sebesar 5,00. Sementara itu, nilai rata-rata yang dimiliki variabel Kompetensi sebesar 4,38 dan standar deviasi sebesar 0,43. Hasil standar deviasi yang kurang dari 1 menunjukan bahwa variabel Kompetensi bersifat homogen. Lebih lanjut, pada variabel Fee Audit memiliki nilai minimum sebesar 2,40 dan nilai maksimum sebesar 5,00. Sedangkan nilai rata-rata yang diperoleh pada variabel Fee Audit sebesar 3,56 dengan standar deviasi 0,55. Hasil standar deviasi yang kurang dari 1 menunjukan bahwa variabel Fee Audit bersifat homogen. Selanjutnya variabel Time Pressure Budget memiliki nilai minimum sebesar 2,50 dan nilai maksimum sebesar 5,00. Sedangkan nilai rata-rata yang diperoleh pada variabel Time Pressure Budget sebesar 3,68 dengan standar deviasi 0,65. Hasil standar deviasi yang kurang dari 1 menunjukan bahwa variabel Time Pressure Budget bersifat homogen. Sementara itu, Kualitas Audit memiliki nilai minimum sebesar 1,00 dan maksimum sebesar 5,00 dengan nilai mean sebesar 4,04 menghasilkan standar deviasi sebesar 1,07. Hasil standar deviasi yang lebih dari 1 menunjukan bahwa variabel Kualitas Audit bersifat heterogen.

Tabel 3. Hasil Uji Validitas Item Pernyataan

\begin{tabular}{|l|c|c|c|}
\hline Item Pernyataan & Pearson Correlation & p-value & Hasil Uji \\
\hline \multicolumn{4}{|c|}{ Etika Auditor (X1) } \\
\hline Panggung Jawab \\
Pernyataan 1 & $0,688^{* *}$ & 0,000 & Valid \\
Pernyataan 2 & $0,709^{* *}$ & 0,000 & Valid \\
Pernyataan 3 & $0,581^{* *}$ & 0,000 & Valid \\
\hline \multicolumn{4}{|c|}{ Profesi Auditor } \\
\hline
\end{tabular}


ProBank : J urnal Ekonomi Dan Perbankan

\begin{tabular}{|c|c|c|c|}
\hline Item Pernyataan & Pearson Correlation & p-value & Hasil Uji \\
\hline Pernyataan 5 & $0,522 * *$ & 0,000 & Valid \\
\hline \multicolumn{4}{|c|}{ Integritas } \\
\hline Pernyataan 6 & $0,650 * *$ & 0,000 & Valid \\
\hline Pernyataan 7 & $0,669 * *$ & 0,000 & Valid \\
\hline Pernyataan 8 & $0,646^{* *}$ & 0,000 & Valid \\
\hline Pernyataan 9 & $0,445^{* *}$ & 0,000 & Valid \\
\hline \multicolumn{4}{|c|}{ Obyektifitas } \\
\hline Pernyataan 10 & $0,658 * *$ & 0,000 & Valid \\
\hline Pernyataan 11 & $0,634 * *$ & 0,000 & Valid \\
\hline \multicolumn{4}{|c|}{ Kompetensi $(X 2)$} \\
\hline \multicolumn{4}{|c|}{ Pengetahuan Umum } \\
\hline Pernyataan 1 & $0,707 * *$ & 0,000 & Valid \\
\hline Pernyataan 2 & $0,627 * *$ & 0,000 & Valid \\
\hline Pernyataan 3 & $0,725^{* *}$ & 0,000 & Valid \\
\hline Pernyataan 4 & $0,764 * *$ & 0,000 & Valid \\
\hline Pernyataan 5 & $0,754 * *$ & 0,000 & Valid \\
\hline Pernyataan 6 & $0,725 * *$ & 0,000 & Valid \\
\hline Pernyataan 7 & $0,527 * *$ & 0,000 & Valid \\
\hline \multicolumn{4}{|c|}{ Pengalaman Audit } \\
\hline Pernyataan 8 & $0,741 * *$ & 0,000 & Valid \\
\hline Pernyataan 9 & $0,596^{* *}$ & 0,000 & Valid \\
\hline Pernyataan 10 & $0,732 * *$ & 0,000 & Valid \\
\hline \multicolumn{4}{|c|}{ Fee Audit (X3) } \\
\hline \multicolumn{4}{|c|}{ Struktur Biaya Audit } \\
\hline Pernyataan 1 & $0,650^{* *}$ & 0,000 & Valid \\
\hline Pernyataan 2 & $0,698 * *$ & 0,000 & Valid \\
\hline Pernyataan 3 & $0,481 * *$ & 0,000 & Valid \\
\hline \multicolumn{4}{|c|}{ Kompleksitas Jasa yang Diberikan } \\
\hline Pernyataan 4 & $0,560 * *$ & 0,000 & Valid \\
\hline Pernyataan 5 & $0,589 * *$ & 0,000 & Valid \\
\hline \multicolumn{4}{|c|}{ Kualitas Audit (Y) } \\
\hline \multicolumn{4}{|c|}{ Kesesuaian Pemeriksaan dengan Standar Audit } \\
\hline Pernyataan 1 & $0,947 * *$ & 0,000 & Valid \\
\hline Pernyataan 2 & $0,944 * *$ & 0,000 & Valid \\
\hline Pernyataan 3 & $0,954 * *$ & 0,000 & Valid \\
\hline Pernyataan 4 & $0,957 * *$ & 0,000 & Valid \\
\hline Pernyataan 5 & $0,947 * *$ & 0,000 & Valid \\
\hline Pernyataan 6 & $0,954 * *$ & 0,000 & Valid \\
\hline \multicolumn{4}{|c|}{ Kualitas Hasil Audit } \\
\hline Pernyataan 7 & $0,961 * *$ & 0,000 & Valid \\
\hline Pernyataan 8 & $0,935^{* *}$ & 0,000 & Valid \\
\hline Pernyataan 9 & $0,959 * *$ & 0,000 & Valid \\
\hline Pernyataan 10 & $0,887 * *$ & 0,000 & Valid \\
\hline Pernyataan 11 & $0,947 * *$ & 0,000 & Valid \\
\hline Pernyataan 12 & $0,830^{* *}$ & 0,000 & Valid \\
\hline Pernyataan 13 & $0,709 * *$ & 0,000 & Valid \\
\hline
\end{tabular}

Sumber: Data Diolah secara Statistik, 2020

Hasil uji validitas item pernyataan yang disajikan pada Tabel 3, dapat dijelaskan bahwa keseluruhan item memiliki p-value $<0,05$ yang berarti item-item yang digunakan adalah valid. Artinya item-item pernyataan yang digunakan dalam instrumen penelitian memiliki validitas konstruk yang baik. Dengan kata lain terdapat konsistensi internal dalam penyataan-pernyataan tersebut sehingga dapat membentuk konstruk dari Etika Auditor, Kompetensi, Fee Audit, dan Time Pressure Budget serta Kualitas Audit sehingga dapat dinyatakan sahih.

Tabel 4.Hasil Uji Reliabilitas Instrumen Penelitian

\begin{tabular}{|l|c|c|c|}
\hline \multicolumn{1}{|c|}{ Variabel } & Jumlah Item & $\begin{array}{c}\text { Cronbach } \\
\text { Coefficients Alpha }\end{array}$ & Hasil Uji \\
\hline Etika Auditor (X1) & 11 & 0,807 & Reliabel \\
Kompetensi (X2) & 10 & 0,865 & Reliabel \\
Fee Audit (X3) & 5 & 0,645 & Reliabel \\
Time Pressure Budget (X4) & 8 & 0,831 & Reliabel \\
Kualitas Audit (Y) & 13 & 0,984 & Reliabel \\
\hline
\end{tabular}

Sumber: Data Diolah secara Statistik, 2020 
Hasil uji reliabilitas instrumen penelitian yang disajikan pada Tabel 4, dapat dijelaskan bahwa keseluruhan instrumen yang terdiri dari konstruk Etika Auditor, Kompetensi, Fee Audit, dan Time Pressure Budget serta Kualitas Audit memiliki nilai minimal Cronbach's Alpha sebesar 0,6 dengan metode Corrected Item Total Correlation. Artinya, Dengan item pernyataan atau keseluruhan variabel yang digunakan dinyatakan reliabel atau andal bahwa indikator-indikator yang digunakan mempunyai ketepatan, keakuratan dan kestabilan atau konsisten yang tinggi.

Hasil uji asumsi klasik diawali dengan uji multikolineartias dengan hasil statistik berikut ini:

Tabel 5.Hasil Uji Multikolinearitas

\begin{tabular}{|l|c|c|c|}
\hline \multicolumn{1}{|c|}{ Variabel Independen } & Tolerance & Variance Inflation Factors & Hasil Uji \\
\hline Etika Auditor (X1) & 0,509 & 1,963 & tidak multikol \\
Kompetensi (X2) & 0,402 & 2,489 & tidak multikol \\
Fee Audit (X3) & 0,663 & 1,508 & tidak multikol \\
Time Pressure Budget (X4) & 0,801 & 1,248 & tidak multikol \\
\hline
\end{tabular}

Sumber: Data Diolah secara Statistik, 2020

Hasil uji multikolinearitas yang disajikan pada Tabel 5, masing-masing variabel independen diperoleh nilai tolerance untuk keempat variabel independen yaitu Auditor, Kompetensi, Fee Audit, dan Time Pressure Budget > 0,1 dan nilai VIF < 10, artinya keempat variabel bebas tersebut terbebas dari masalah multikolinearitas, atau dengan kata lain antar variabel bebas yang diuji tidak saling berkorelasi. Uji normalitas menggunakan One Sample Kolmogorov-Smirnov (K/S) Test dengan menggunakan taraf signifikansi 0,05 .

Tabel 6.Hasil Uji Kolmogorov-Smirnov
\begin{tabular}{|l|c|}
\hline & Skor \\
\hline N & 63 \\
Kolmogorov-Smirnov Z & 0,540 \\
Probabilitas Signifikansi & 0,965 \\
\hline
\end{tabular}

Sumber: Data Diolah secara Statistik, 2020

Hasil uji normalitas yang disajikan pada Tabel 6, nilai signifikansi untuk unstandardized residual sebesar 0,965. Nilai ini signifikan untuk unstandardized residual pada model tersebut lebih besar dari 0,05 , artinya data pada model regresi dalam penelitian ini telah berdistribusi normal.

Hasil uji hipotesis diawali dengan uji koefisien determinasi $\left(\mathrm{R}^{2}\right)$ dengan hasil statistik berikut ini:

\begin{tabular}{|l|c|}
\multicolumn{2}{|c|}{ Tabel 7.Hasil Uji R ${ }^{2}$} \\
\hline $\mathrm{R}$ & Skor \\
\hline Adjusted R-Square & 0,469 \\
\hline
\end{tabular}

Sumber: Data Diolah secara Statistik, 2020

Hasil uji R-Square yang disesuaikan (Adj.) disajikan pada Tabel 7, skor adalah 0,166 yang berarti kontribusi pengaruh dari Etika Auditor, Kompetensi, Fee Audit dan Time Pressure Budget terhadap Kualitas Audit sebesar 16,6 persen, sedangkan sisanya sebesar 83,4 persen merupakan kontribusi pengaruh dari faktor-faktor lain yang tidak dianalisis dalam penelitian ini. Hasil uji hipotesis secara simultan (ANOVA) dengan hasil statistik berikut ini:

Tabel 8.Hasil Uji Simultan

\begin{tabular}{|l|c|}
\hline & Skor \\
\hline $\mathrm{dF}(1 ; 2)$ & $4 ; 58$ \\
F-Statistik & 4,090 \\
Probabilitas Signifikansi & 0,005 \\
\hline
\end{tabular}

Sumber: Data Diolah secara Statistik, 2020

Hasil uji F disajikan pada Tabel 8, skor F-statistik adalah 4,090 atau dengan melihat signifikansi skor sebesar 0,005 (lebih kecil dari 0,05), artinya Ha diterima. Pengaruh seluruh variabel independen (Etika Auditor, Kompetensi, Fee Audit dan Time Pressure Budget) terhadap Kualitas Audit adalah 
signifikan secara simultan. Hasil uji hipotesis secara simultan (ANOVA) dengan hasil statistik berikut ini:

Tabel 9.Hasil Uji t

\begin{tabular}{|l|c|c|c|c|}
\hline \multicolumn{1}{|c|}{ Variabel Independen } & Coefficients & t-statistik & p-value & Kesimpulan \\
\hline Constant & 0,663 & 0,443 & 0,660 & - \\
Etika Auditor (X1) & 1,132 & 2,589 & 0,012 & $\mathrm{H}_{1}$ Diterima \\
Kompetensi (X2) & $-1,044$ & $-2,283$ & 0,026 & $\mathrm{H}_{2}$ Diterima \\
Fee Audit (X3) & 0,795 & 2,850 & 0,006 & $\mathrm{H}_{3}$ Diterima \\
Time Pressure Budget (X4) & 0,022 & 0,104 & 0,917 & $\mathrm{H}_{4}$ Ditolak \\
\hline
\end{tabular}

Sumber: Data Diolah secara Statistik, 2020

Hasil uji t disajikan pada Tabel 9, skor t-statistik masing-masing variabel Etika Auditor (X1), Kompetensi (X2), Fee Audit (X3) dan Time Pressure Budget (X4) adalah 2,589, minus 2,283, 2,850, dan 0,104 atau dengan melihat masing-masing signifikansi skor sebesar 0,012, 0,026, dan 0,006 (lebih kecil dari 0,05) untuk X1, X2 dan X3 sementara X4 lebih besar dari 0,05 yaitu 0,917, artinya $\mathrm{H}_{1}, \mathrm{H}_{2}$, dan $\mathrm{H}_{3}$ diterima sementara $\mathrm{H}_{4}$ ditolak. Pengaruh masing-masing variabel independen yang terdiri dari Etika Auditor dan Fee Audit berpengaruh positif, Kompetensi berpengaruh negatif dan keduanya memiliki signifikansi sementara Time Pressure Budget tidak berpengaruh signifikan terhadap Kualitas Audit.

\section{PEMBAHASAN}

Variabel X1 yang merupakan Etika Auditor berdasarkan hasil uji t pada Tabel 9 memiliki koefisien regresi dengan skor 1,132, artinya berpengaruh positif dengan probabilitas signifikansi sebesar 0,012 yang artinya signifikan. Hasil ini menunjukkan bahwa semakin baik Etika Auditor yang dimiliki maka berdampak pada peningkatan Kualitas Audit secara signifikan. Temuan penelitian mendukung agency theory yang menyatakan bahwa faktor etika auditor yang berasal dari Kantor Akuntan Publik (KAP) di Jakarta dipersepsikan responden yang menjadi sampel mampu meningkatkan kualitas audit dan mampu mengurangi adanya asimetris informasi dan konflik keagenan. Hasil penelitian mendukung riset sebelumnya yang menemukan pengaruh positif dan signifikan atas faktor etika auditor atas kualitas audit (Hanjani \& Rahardja, 2014; Kurnia, Khomsiyah, \& Sofie, 2014; Chrisdinawidanty, Tugiman, \& Muslih, 2016). Etika profesi tidak hanya diharus diterapkan oleh seorang auditor, melainkan pada setiap individu dari berbagai jenis profesi.

Variabel X2 yang merupakan Kompetensi berdasarkan hasil uji t pada Tabel 9 memiliki koefisien regresi dengan skor minus 1,044, artinya berpengaruh negatif dengan probabilitas signifikansi sebesar 0,026 yang artinya signifikan. Hasil ini menunjukkan bahwa semakin tinggi Kompetensi yang dimiliki seorang auditor maka berdampak pada menurunnya Kualitas Audit secara signifikan. Temuan penelitian tidak mendukung seluruh riset sebelumnya yang menemukan bahwa kompetensi berpengaruh positif secara signifikan atas kualitas audit (Alim, Hapsari, \& Purwanti, 2007; Tjun, Marpaung, \& Setiawan, 2012; Cahaya Ningsih \& Yaniartha S., 2013; Kurnia, Khomsiyah, \& Sofie, 2014), sementara penelitian ini menyatakan bahwa sebaliknya kompetensi berpengaruh negatif secara signifikan atas kualitas audit. Pencapaian kompetensi pada penelitian ini lebih memfokuskan pada arah penurunan kualitas audit.

Variabel X3 yang merupakan Fee Audit berdasarkan hasil uji t pada Tabel 9 memiliki koefisien regresi dengan skor 0,795, artinya berpengaruh positif dengan probabilitas signifikansi sebesar 0,006 yang artinya signifikan. Hasil ini menunjukkan bahwa semakin tinggi Fee Audit maka berdampak pada peningkatan Kualitas Audit secara signifikan. Hasil penelitian mendukung riset sebelumnya yang menemukan pengaruh positif dan signifikan atas faktor Fee Audit atas kualitas audit (Hanjani \& Rahardja, 2014; Chrisdinawidanty, Tugiman, \& Muslih, 2016). Semakin tinggi Fee Audit pada penelitian ini akan sangat menentukan dalam merumuskan dan memberi jaminan atas kualitas audit oleh KAP.

Variabel X4 yang merupakan Time Pressure Budget berdasarkan hasil uji t pada Tabel 9 memiliki koefisien regresi dengan skor 0,022 , artinya berpengaruh positif dengan probabilitas signifikansi sebesar 0,917 yang artinya tidak signifikan. Hasil ini menunjukkan bahwa semakin tinggi 
Time Pressure Budget Audit maka tidak berdampak pada peningkatan atau penurunan Kualitas Audit secara signifikan. Temuan penelitian tidak mendukung signalling theory yang menyatakan bahwa manajer perusahaan yang berkinerja tertentu akan memberi sinyal positif atau negatif, kaitannya dengan tekanan waktu dalam perencanaan auditor eksternal tidak menjadi patokan dalam peningkatan kualitas audit dalam penelitian ini. Hasil penelitian mendukung riset sebelumnya yang menemukan tidak berpengaruhnya tekanan waktu atas kualitas audit (Sososutikno, 2003) sementara menolak temuan riset Cahaya Ningsih dan Yaniartha S. (2013) serta Kurnia, dkk. (2014) dan Wahyudi dengan membuktikan pengaruh negatifnya atas kualitas audit. Auditor dalam melakukan perencanaan audit yang telah berpedoman pada Standar Audit (SA) tentunya akan sangat baik berpedoman tanpa mengindahkan adanya time pressure khususnya yang menempatkan tim audit yang memiliki jam terbang yang tinggi sehingga mampu menyelesaikan penugasan audit yang diberikan baik tanpa adanya time pressure khususnya yang dituangkan dalam perikatan audit.

\section{PENUTUP}

\section{Simpulan}

Penelitian yang bertujuan untuk menganalisis dan membuktikan secara empiris determinan faktor yang berpengaruh atas kualitas audit pada Kantor Akuntan Publik (KAP) yang terdiri dari Etika Auditor, Kompetensi, Fee audit serta Time Pressure Budget dibuktikan oleh Etika Auditor dan Fee Audit yang berpengaruh positif atas Kualitas Audit sementara Kompetensi berpengaruh sebaliknya atau negatif atas Kualitas Audit. Time Pressure Budget tidak berpengaruh signifikan atas Kualitas Audit. Kontribusi determinan faktor hanya 16,6 persen yang mampu menjelaskan Kualitas Audit dari keempat faktor yang berpengaruh di atas, yang artinya masih banyak faktor-faktor lainnya yang tidak dilibatkan pada penelitian ini sehingga temuan penelitian ini tidak dapat digeneraliasi secara umum pada auditor yang berkerja pada KAP di wilayah Jakarta.

\section{Saran}

Saran penelitian ini yaitu: (1) Perluasan subjek penelitian dapat diperluas tidak hanya pada auditor yang bekerja pada KAP di wilayah Jakarta saja melainkan dapat diperluas setidaknya pada KAP Jabodetabek bahkan Pulau Jawa untuk lebih mampu memperkaya hasil penelitian. (2) Penambahan faktor-faktor lainnya yang dapat mempengaruhi Kualitas Audit antara lain pengalaman audit, pertimbangan profesional auditor, dan faktor lainnya dapat dilibatkan pada penelitian mendatang agar dapat meningkatkan kontribusi faktor penentu kualitas audit dengan lebih baik. (3) Studi empiris menggunakan data sekunder untuk memperkaya khasanah bidang akuntansi dan audit dalam konteks pengukuran kualitas audit.

\section{DAFTAR PUSTAKA}

Aditia, I. (2016). Pengaruh Fee Audit terhadap Kualitas Audit dan Dampaknya terhadap Independensi Auditor (Survey Pada 11 Kantor Akuntan Publik yang Terdaftar di Otoritas Jasa Keuangan Kota Bandung). Bandung: FE Universitas Pasundan.

Adnan, F. A. (2017). Pengaruh Kompetensi, Independensi Auditor, Profesionalisme, dan Fee Audit terhadap Kualitas Audit (Survei pada Auditor yang Bekerja pada KAP di Surakarta dan Semarang). Surakarta: FEB Universitas Muhammadiyah.

Agoes, S. (2012). Auditing Petunjuk Praktis Pemeriksaan Akuntan oleh Akuntan Publik (Jilid-1) (4 ed.). Jakarta: Salemba Empat.

Alim, M. N., Hapsari, T., \& Purwanti, L. (2007). Pengaruh Kompetensi dan Independensi terhadap Kualitas Audit dengan Etika Auditor sebagai Variabel Moderasi. Simposium Nasinal Akuntansi X. AUEP-08, pp. 1-26. Makassar: Universitas Hasanuddin. 
Arens, A. A., Elder, R. J., \& Beasley, M. S. (2014). Auditing and Assurance Service, an Integrated Approach (Global ed.). England: Pearson Education Limited.

Cahaya Ningsih, A. P., \& Yaniartha S., P. D. (2013). Pengaruh Kompetensi, Independensi, dan Time Budget Pressure terhadap Kualitas Audit. E-Jurnal Akuntansi Universitas Udayana, 4(1), 92109.

Chrisdinawidanty, Z. N., Tugiman, H., \& Muslih, M. (2016). Pengaruh Etika Auditor Dan Fee Audit Terhadap Kualitas Audit (studi Kasus Pada Kantor Akuntan Publik Di Bandung). eProceedings of Management, 3(3), 3466-3474.

Chung, D. Y., \& Lindsay, W. D. (1988). The Pricing of Audit Services: The Canadian Perspective. Contemporary Accounting Research, 5(1 Fall), 19-46.

DeFond, \& Zhang, J. (2014). A review of archival auditing research. Journal of Accounting and Economics, 58(2-3), 275-326.

Godfrey, J., Hodgson, A., Tarca, A., Hamilton, J., \& Holmes, S. (2010). Accounting Theory (7 ed.). New York: McGraw Hill.

Hanjani, A., \& Rahardja. (2014). Pengaruh Etika Auditor, Pengalaman Auditor, Fee Audit, Dan Motivasi Auditor Terhadap Kualitas Audit (Studi pada Auditor KAP di Semarang). Diponegoro Journal of Accounting, 3(2), 111-119.

Hoitash, R., Markelevich, A., \& Barragato, C. A. (2007). Auditor fees and audit quality. Managerial Auditing Journal, 22(8), 761-786.

Husain, T. (2017). Analisis Determinan Faktor-Faktor Yang Mempengaruhi Niat Penggunaan Software Audit. Jurnal Ilmiah Matrik, 19(2), 131-150.

Jensen, M. C., \& Meckling, W. H. (1976). Theory of the firm: Managerial behavior, agency costs and ownership structure. Journal of Financial Economics, 3(4), 305-360.

Kaptein, M. C., Nass, C., \& Markopoulos, P. (2010). Powerful and consistent analysis of likert-type rating scales. In E. Mynatt (Ed.), CHI '10: Proceedings of the SIGCHI Conference on Human Factors in Computing Systems (pp. 2391-2394). Atlanta Georgia USA: SIGCHI.

Kell, W. G., Johnson, R. N., \& Boynton, W. C. (2002). Modern Auditing (Jilid I) (7 ed.). Jakarta: Penerbit Erlangga.

Khristiana, Y., \& Sapariyah, R. A. (2016). Kinerja Keuangan Perbankan Syariah dengan Dimensi Profitabilitas. BHIRAWA - Journal of Marketing and Commerce, 4(1), 31-40.

Kurnia, W., Khomsiyah, \& Sofie. (2014). Pengaruh Kompetensi, Independensi, Tekanan Waktu dan Etika Auditor Terhadap Kualitas Audit. e-Journal Akuntansi Fakultas Ekonomi, 1(2), 49-67.

Lianto, N., \& Kusuma, B. H. (2010). Faktor-Faktor Yang Berpengaruh Terhadap Audit Report LAG. JURNAL BISNIS DAN AKUNTANSI, 12(2), 98-107.

Nurhayati. (2017). Peranan Good Governance dan Independensi Auditor terhadap Kinerja Auditor. Majalah Ilmiah Warta Dharmawangsa, 51.

Nurul Ichsany, S. W., \& Husain, T. (2018). Frekuensi Pertemuan Dewan Komisaris dan Komite Audit Terhadap Manajemen Laba Dengan Pendekatan Non-Discreationary Accruals. Journal Management, Business, and Accounting, 17(2), 34-46.

Purba, D. M. (2019). Pengaruh Kualitas Laba dan Rasio Keuangan Terhadap Kualitas Audit. Jurnal Akuntansi dan Governance Andalas, 2(2), 89-104.

Rapina, Saragi, L. M., \& Carolina, V. (2010). Pengaruh Independensi Eksternal Auditor terhadap Kualitas Pelaksanaan Audit. Akurat Jurnal Ilmiah Akuntansi, 1(2).

Ridwan, \& Husain, T. (2017). Pengaruh Independensi, Pengalaman, Dan Pertimbangan Profesional Auditor Terhadap Kelengkapan Bahan Bukti Audit (Studi Empiris Pada Kantor Akuntan Publik di DKI Jakarta). Mabiska Jurnal, 2(1), 1-15.

Sani, A., \& Maharani, V. (2013). Metodologi Penelitian Manajemen Sumber Daya Manusia (Teori, Kuesioner dan Analisis Data), Cetakan Ke-2. Malang: UIN MALIKI Press.

Sani, A., Pusparini, N. N., Rizal, R., Khristiana, Y., Zailani, A. U., \& Husain, T. (2020). E-Business Adoption Models in Organizational Contexts on The TAM Extended Model: A Preliminary Assessment. 8th International Conference on Cyber and IT Service Management (CITSM 2020). Pangkalpinang: UIN Syarif Hidayatullah.

Sani, A., Wiliani, N., \& Husain, T. (2019). Spreadsheet Usability Testing in Nielsen's Model among Users of ITSMEs to Improve Company Performance. European Journal of Scientific Exploration, 2(6), 1-9. 
Singgih, E. M., \& Bawono, I. R. (2010). Pengaruh Pengalaman, Independensi, Due Professional Care, dan Akuntabilitas Terhadap Kualitas Audit (Studi pada Auditor di KAP "Big Four" Indonesia). Simposium Nasinal Akuntansi XIII (pp. 1-24). Purwekerto: Universitas Jenderal Soedirman.

Sososutikno, C. (2003). Hubungan Tekanan Anggaran Waktu dengan Perilaku Disfungsional serta Pengaruhnya terhadap Kualitas Audit. Simposium Nasional Akuntansi VI, 6. Surabaya.

Sugiyono. (2018). Metode Penelitian Evaluasi: Pendekatan Kuantitatif, Kualitatif, dan Kombinasi. Bandung: CV. Alfabeta.

Tjun, L. T., Marpaung, E. I., \& Setiawan, S. (2012). Pengaruh Kompetensi dan Independensi Auditor Terhadap Kualitas Audit. Jurnal Akuntansi, 4(1), 33-56.

Trisyanto, A. (2019). Analisa Pengaruh Solvabilitas, Profitabilitas, Total Aset, Umur Perusahaan terhadap Audit Delay pada Perusahaan yang Terdaftar di BEI. Jurnal Buana Akuntansi, 4(1). 